\title{
RELIGIOUS PRACTICES AND LOCAL MAGIC OF INLAND MALAY SOCIETY IN WEST KALIMANTAN
}

\author{
Hermansyah \\ State Institute of Islamic (IAIN) Pontianak \\ hermansyahii@yahoo.com
}

\begin{abstract}
Belief and practice as part of culture which exists in society is the result of a dynamic process that is growing and developing, and affected by both internal and external aspects of the society. All of this is a manifestation of a continuity of the treasures of humanity. Derivation and transfer of a culture toward forming a new more complex culture is natural and inevitable. There is no culture and civilization in the world built without relationship and interchange with other cultures and civilizations. It is also the case with the religious life of the rural community in West Kalimantan which is the subject of the study in this article. This continuity shows that local communities have a vibrant culture passed down from one generation to the next. The existence of tradition heritage recorded in magic called ilmu in inland Islamic societies of West Kalimantan shows that their peaceful process of accepting Islam since its spread, to a certain extent, accommodates local culture. The dialectic process of Islam and local culture serves as an example of religious acceptance in a massive fashion in a region far away from the coastal area.
\end{abstract}

Keywords: ilmu, magic, Islam, local culture,

\section{INTRODUCTION}

Even though Islam does not formally teach magic, it is undeniable that some followers of the religion practice magic. In fact, since the end of the 19th century until the early 20th century, the practice of magic of Indonesian Islamic communities has attracted the attention of colonial officials and western scientists. A great deal of works about the practice of magic in Indonesian Islamic societies have been published through journals and books. The most phenomenal book about the magic of Indonesian Islamic societies, particularly in Peninsular Malaysia, written by Skeat was first published in 1900. Over the span of 100 years since the publication of the book, there have been a variety of works about magic in the Malay world, in the form of books 
and journal articles. These works were written among others by Maxwell (1883), Winstedt (1920, 1985), Hamilton (1926), Shaw (1972, 1975), Werner (1986) Endicott (1991), Laderman (1991), Hopes (1997), Haron David (2001), and Hermansyah (2005).

This paper specifically addresses the practice of magic in the inland communities of West Kalimantan, especially in the area of Embau. This paper discusses the relationship between belief and practices of local communities before and after Islam. As a compative work for this paper, Hasse J. (2011) did a great work of the dynamics of Islam and local belief in which some challenges are found especially in the issue of bargaining values between the two. I have found in the community that the practice of magic, as it had already existed, does not necessarily disappear with the coming of Islam, and even partially shows syncretism between Islam and local magic.

\section{EMBAU AREA}

This research was carried out in the area of Embau which is the name of one of the tributaries of the Kapuas river --the longest in Indonesia. From 1800 through 1857, the Embau area, an administrative area (see Map 2) was under the Semitau colonial rule with an administrative name Embau. Later in 1858, Embau was separated from Semitau and governed directly by the ruling King of Jongkong under Dutch colonial rule. According Marzoeki (1939) in 1882 Jongkong became a Landschap ruled by King Sulaiman Suria Negara. In December 1899, Abang Alam whose royal title was Pangeran Muda Gusti Alam succeeded his father as King of Jongkong. In 1917 the Landschap government of Jongkong was abolished and changed to a Gouvernementsgebeid; Pangeran Muda Gusti Alam received $£ 1,000$ compensation and ceased to be king.

At that time Jongkong was made under the rule of Embau Districtshoofd located in Gagak village, while Jongkong was only governed by a village elder, Raden Nata, a former royal minister of Jongkong. In 1920 there was a Grootkamponghoofd or Complexhoofd and Raden Nata who ruled at that time was successively replaced by Gusti Hamzah and Ade M. Dahlan and Aris bin Kebuk. Meanwhile, the entire area of Embau was led by a Demang until the middle of 1952. By the end of 1952, Embau was led by a District Assistant Officer until 1960 (Abdullah 1988).

Later, Embau was divided into two subdistrict administrative areas, i.e.: Subdistrict of Embau and Subdistrict Hulu Gurung until January 1997. Since the creation of new district policy, the Embau area was divided into three subdistricts. Subdistrict of Embau was divided into two subdistricts i.e. 
Jongkong subdistrict Jongkong with Jongkong as the capital and Batu Datu subdistrict -which is a division of the Embau Subdistrict with Menendang as the capital. ${ }^{1}$ Meanwhile the SubHulu Gurung Subdistrict whose capital is Nanga Tepuai has not changed.

\section{Map 1. Embau Area}

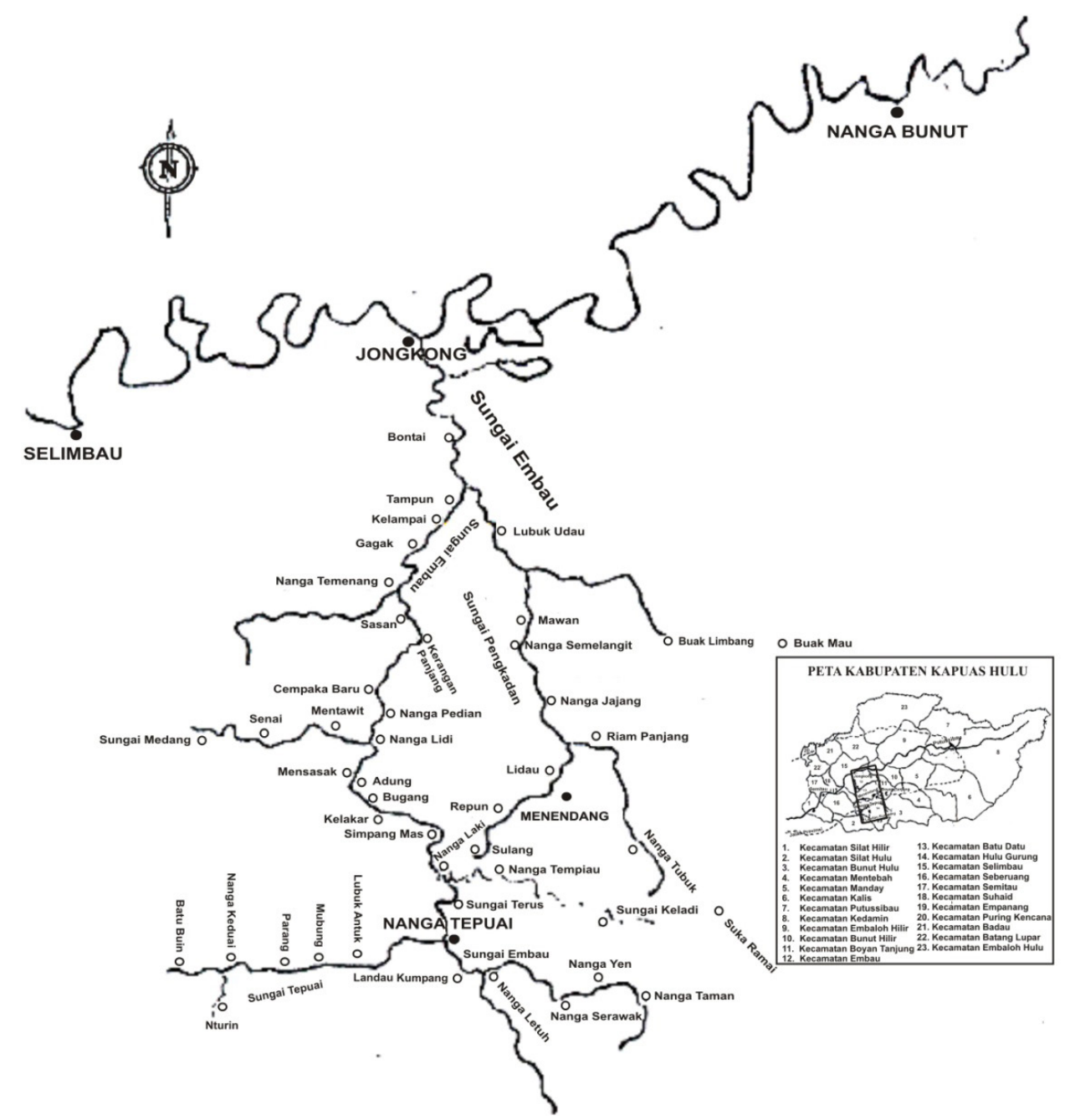

Source: Hermansyah $2010: 2$

${ }^{1}$ The north of the Embau region is bordered by Batang Lupar Subdistrict and Suhaid Subdistrict, the east by Bunut Hilir and Boyan Tanjung Subdistricts, the south by the Silat Hulu Subdistrict, and the west by the Seberuang and Selimbau Subdistricts. 
Despite the fact that the Embau area or even the Kapuas Hulu Regency as a whole is an inland region often perceived as the areas of wilderness, it can be reached by traditional means of river transport called mutur and tempil (Yusriadi, 1999). All regions in Kapuas Hulu can be accessed through the river, especially the Kapuas River and its tributaries. Nevertheless, the assumption is not quite wrong as until the end of the 19th century, this area was still a 'white area on the map "(Sellato, 1994). It prompted the Dutch colonial government to conduct an expedition to the region by sending Doctor A.W. Nieuwenhuis ${ }^{2}$ in 1893. The expedition itself was intended to set up a real territorial control based on the structure of the administration and the military.

Map 2. Embau area from 1800 to 1857

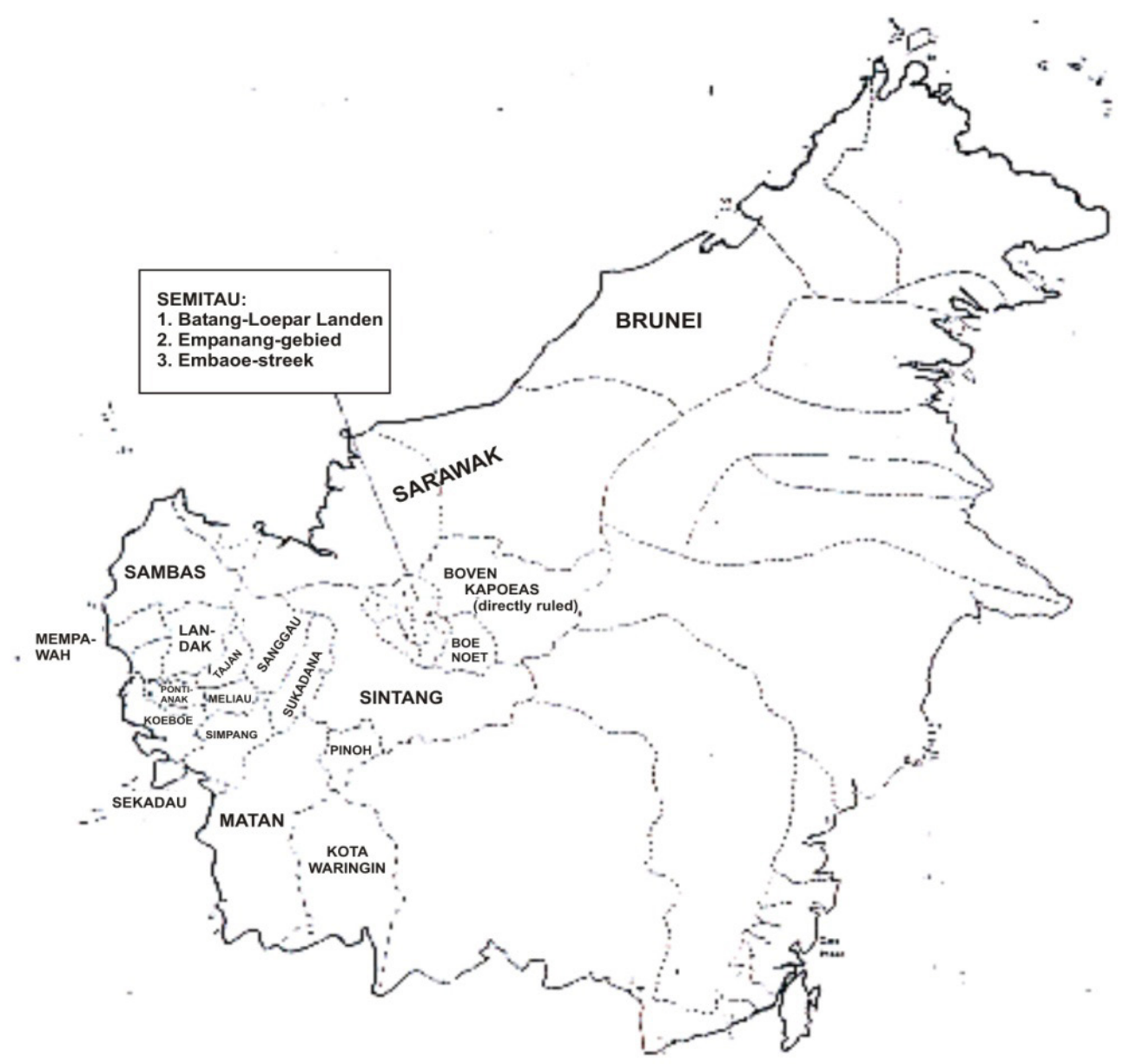

Source: Cribb 2000

${ }^{2}$ See Sellato (1994: 13-22) for description of Nieuwenhuis and other pioneer colonial officials. 
The total area of Embau is $1386.60 \mathrm{~km}^{2}$ or $138,660 \mathrm{ha}$, which is $4.65 \%$ of the total area of Kapuas Hulu $\left(29,842 \mathrm{~km}^{2}\right)$ covered with plains and hills. The lowlands are mainly situated on the riverside in Embau Subdistrict, while the Batu Datu Subdistrict and Hulu Gurung Subdistrict generally consist of plateaus and hills. Most of the available land has generally been used by residents for rubber and oil palm plantations, rice farms and fields. Additionally, in Embau Subdistrict there is also a lake which is also where upstream tributaries are located. When the dry season comes, this lake is a place to fish for local fishermen.

Like the other regions of Borneo in general, Embau has a tropical climate with temperatures ranging between $22.9^{\circ} \mathrm{C}$ and $31.05^{\circ} \mathrm{C}$ with average daytime temperature of $29^{\circ} \mathrm{C}$. The rainfall rate in this region is quite high i.e. between $4,437.5 \mathrm{~mm}$ and 4,727 $\mathrm{mm}$ with 313 rainy days a year. The number of rainy days which is quite high accompanied by very heavy rainfall has caused the forests in this area to be quite dense and lush. However, now due to the policy of the Forest Concession (HPH) a few years ago, the forests in the Embau region have very much been cleared. Meanwhile according to the census report of Central Agency of Statistics of Kapuas Hulu (BPS 2004) at the end of 2003 there were 29,034 people in the area of Embau or 15\% of the total population of Kapuas Hulu (193,616 people) made up of 14,727 males (50.72\%) and 14,307 females $(49.28 \%)$.

Embau's largest population resides in the region of Hulu Gurung Subdistrict with 10,704 people (36.87\%) occupying an area of $432.90 \mathrm{~km}^{2}$ with an average of 25 people per kilometer. The population of Jongkong Subdistrict amounted to $9,803(33.76 \%)$ with a total area of $422.50 \mathrm{~km}^{2}$ and with an average spread of population 23 people per kilometer. Menwhile, Batu Datu Subistrict residents amounted to $8,527(29.37 \%)$ with a total area of $531.20 \mathrm{~km}^{2}$, or an average of 16 people per kilometer.

Embau's population density is much lower when compared to the population density of Java where every kilometer is inhabited by 779 people or population of the island of Sumatra where every kilometer has a population of 93 people. The population density in Embau is even far below the average of Indonesia, which is 114 people per kilometer (BPS 2003: 65).

Embau's residents, in terms of ethnic and religious affiliations, are unique, especially when compared with residents of other areas in Kapuas Hulu. In contrast to the prevailing circumstances of Kapuas Hulu which reflects a diversity of ethnicity and religion, the entire population of the natives (indigenous people) of Embau embraces Islam and claim to be ethnic Malay. ${ }^{3}$

${ }^{3}$ For example, in Subdistricts to the east of Embau, i.e. Bunut and Nanga Suruk there are non-Muslim community groups called 'Dayak' Suruk and Mentebah. On the north side 
Followers of other religions such as Catholicism, Protestantism and Buddhism are the Chinese who came to Jongkong approximately one hundred years ago ${ }^{4}$. For details about the religions in Embau, see Table 1.

TABLE 1. Population based on Religion

\begin{tabular}{lcc}
\hline \multicolumn{1}{c}{ Religion } & Number of followers & Percentage \\
\hline Islam & 28,731 & 98.96 \\
Catholicism & 281 & 0.97 \\
Protestantism & 12 & 0.04 \\
Buddhism & 10 & 0.03 \\
\hline TOTAL & 29,034 & 100 \\
\hline
\end{tabular}

Source: Adjusted to Kapuas Hulu Ministry of Religious Affairs Office 2005

In general, the researcher simply divided the ethnic inhabitants of this area into two categories, i.e. Malay and Dayak. However, such ethnic distinction has yet to have a solid foundation since there are groups of people who do not fit in both categories such as Pekaki (Pengaki), Senganan and Mmayan. Pekaki people, a transitional community, are classified into neither Malay, even if they are Muslims, nor Dayak (see Bouman Enthoven 1924 and 1903). ${ }^{5}$

Meanwhile, the Senganan are an indigenous group who were assimilated with the Malay people through trade and then converted to Islam. ${ }^{6}$ The Mmayan

there is another non-Muslim community group, the Iban, and on the west there are Suhaid and Mmayan tribes. Compare with Hermansyah (2004).

${ }^{4}$ In addition to embracing Catholicism, Protestantism and Buddhism they also have houses of worship for Confucianism called Pekong. They, to this day, settle only in Jongkong (Embau River estuary) and live in their own group and do not blend in the local community. This kind of pattern placement actually occurs because there are a lot of government regulations that prohibit them from living in places other than subdistrict towns.

${ }^{5}$ King (1993) wrote “... there were peoples called the pengaki or Pekaki Malay, who were Islamized Dayaks. These too remained in longhouses, and apparently continued to follow some Dayak customs, including drinking rice-wine and eating pork. "What was stated by Bouman and Enthoven approximately 100 years ago is not found by the researcher. They already live like Muslims. No more longhouses found in Kanung Suli Lake and Unang Lake (Pengaki village in the west of Jongkong). Also there were no longer habits of eating pork or drinking rice-wine.

${ }^{6}$ This community before converting to Islam also did not know the term Dayak but Nangkut; see Sutini Ibrahim (1995). The term Nangkut is not known in the Embau region. Meanwhile there are similar opinions that explain the existence of Senganan which mention that Senganan or also known by the title "bird Islam" is a group of local people who no longer eat pork, circumcise and get married by Islamic ways and to not drink liquor. They have formally professed to be Muslims but have yet to practice Islamic teachings. Many traditions and rituals before Islam are still practiced. The current findings also explain that they are also not familiar with the term Dayak. The reference to Dayak is not preferred because it gives the 
refer to community groups residing in the Subdistricts of Selimbau and Suhaid partly Muslim and partly Christian. Similarly, there is also a phenomenon of masuk Melayu (literally meaning to become Malay' or 'to enter Malaydom') or turun Melayu ('to come down [and become] Malay) ${ }^{7}$ and Dayak Islam. ${ }^{8}$

\section{HISTORY OF ISLAM IN EMBAU}

Even though in some demographic maps, it is stated that the people of the inland West Kalimantan are non-Muslim Dayaks, the existence of the MalayMuslims in the region has been mentioned since hundreds of years ago. Several scientists who argued that the Malay-Muslim is a tribe that inhabits this region in addition to the Dayak are among others van Kessel (1850), Veth (1854), Nieuwenhuis (1994) and Bouman (1924). Bouman (1924: 173-195), for example, made a quite detailed report about this ethnic group. He stated that there are three ethnic groups in this region, i.e. the Malays, Dayaks and the Foreign Asians. ${ }^{9}$

However, the presence of Muslim-Malays who first occupied this area is not yet known. King (1993) and Sellato (1994) argued that the Muslim-Malays in West Kalimantan originated from Dayaks; thus they are the natives also, together with other tribes in Kalimantan. Veth (1854: 54) reported on Embau population. According to him one's Islamic identity means they hold the title

impression of a low level of civilization. They are happier to be called orang darat (eople of the land) or the name of the sub-tribes such as Iban, Mmayan, Kantuk, etc. (compare with Moh. Haitami, et al, 2000). Sellato (1994: 40,43) mentioned Senganan as a term referring to a type of dialect of Malay and Muslim community groups in Nanga Balang in the upper Kapuas River. Meanwhile, Sellato (2000) in another work stated that Senganan are the Dayak community groups that have converted to Islam in Putussibau, the capital of Kapuas Hulu.

${ }^{7}$ This phenomenon is very common to date. Diversion of religion in this area also requires one to perform redirection of culture to shift the tribal name they bear. Islam has become synonymous with Malay and the other way round. This is in line with the findings by Sellato (1992): "Gradually over time religious conversion would result in a reclassification of the Dayak converts as Malay; the local Malay term for this process is masok Melayu ('to become Malay' or 'to enter Malaydom') or sometimes turun Melayu ('to come down [and become] Malay"'

${ }^{8}$ At the end of 2000, there was a colloquium which discussed the theme of Muslim Dayak in West Kalimantan. The colloquium did not produce scientific agreement about the relationship between religion and ethnicity. Previously, an organization called the Association of the Muslim Dayak Families had emerged (IKDI). No clear criteria for "Muslim Dayak". Are they natives who were previously animists or who have embraced other religions and converted to Islam or those who were indigenous people born with the religion of Islam. This ambiguity was once an important issue in the case of two brothers called Amir and Amin (pseudonyms), one was an executive member of Malay Adat and Cultural Assembly of West Kalimantan (MABM-KB) while the other an executive member of the Association of Muslim Dayak (IKDI).

9 "De bevolking der gouvernementslanden in de Boven-Kapuas, omvattende der onderafdeelingen, Semitau en Boven-Kapoeas, wordt onderscheiden in drie groepen: Dajaks, Maleijers en Vreemde Oosterlinge". 
name of the Malay. Veth (1854: 54) purposefully noted; "Daar zij voor eenige jaren den islam hebben aangenomen thans tot de malaijers kunnen gerekend worden." It means, "a couple of years before, they (residents of Sungai Embau) had converted to Islam, then they should be regarded as the Malays."

Recognition of the Embau as Malay ethnic group, either by themselves or by outsiders, the has long been made, around 200 years ago, i.e. when Islam came and was embraced by the locals. A manuscript written in the year $1241 \mathrm{H}$ or approximately 1827 AD by Pangeran Ratu Idris which tells about the spread of Islam in Kapuas Hulu, including Embau, was carried out by Islamic kingdom of Sintang, when the Kingdom of Sintang was ruled by Ade Rahman a.k.a Abang Pikai and who was styled Sultan Abdurrahman Muhammad Jalaluddin usually referred to as Sultan Aman who ruled from 1150 to $1200 \mathrm{H}( \pm 1737$ $1785 \mathrm{AD})$.

A little different from this manuscript, according to King (1993: 32) the process of Islamization in Embau began in the early 19th century by Pangeran Haji Mohammad Abas and when the Kingdom of Bunut became strong, and it was Abang Barita from Selimbau who continued this effort. However, both of these sources of data are not much different. Perhaps, initial attempts to spread Islam were carried out by Islamic preachers from Sintang to Embau region since the end of the 18th century, but it was more intensive when the Kingdom of Bunut became solid. Furthermore, this effort reached its peak when the Islamic Kingdom of Jongkong was founded in the middle of the 19th century (http://www.manic-raven.com, 2005). Now, there are 47 Embau Malay villages in which all the indigenous populations converted to Islam.

\section{PRACTICE OF MAGIC IN EMBAU}

In daily language, the Embau people use the word $i m u$ to refer to expertise whose anthropological term is magic. The use of the term ilmu is not only prevalent in the community of Embau, but also popular among the people of the Indonesian archipelago. People are familiar with the term ngelmu in Java for example to refer to similar capability. The prevalence of its use can also be compared with the entries of this word in the dictionary compiled by Wilkinson (1959) to refer to roughly the same meaning.

The practice of ilmu in the Embau community can be traced to the history of the community. Traces of pre-Islamic beliefs can be recognized in the practice of Ilmu of Embau people, either in the form of mantra and so on. Before embracing Islam, the Embau people believed in animism. However, other faiths such as Hinduism and Buddhism can also be traced in the Ilmu 
of Embau people. Hindu-Buddhist influence is a common phenomenon to be found in rural communities of West Kalimantan, although no evidence of this society embracing the religion can be found, except in some areas such as Sintang and Ketapang.

Regarding the Hindu influence on the practice and belief of the communities in interior of Kalimantan is presupposed by some authors to originate through a relationship with Java, possibly through the Majapahit Kingdom, though difficult to prove. With regard to this, King (1993: 112) stated:

"Various Dayak Also Populations are reputed to have links with Java, Although the precise of Reviews These connections and when they occurred are difficult, to Determine. The Kedayans of Brunei are said, in some popular reports, to have Originated from Javanese immigration, as have the Dayaks of the Tayan village area of western Borneo. Certain elements of Dayak cultures more can definitely be connected to Indian influence, probably via Javanese Majapahit."

In addition, King (1993: 110) stated:

Symbolic representations of supernatural beings were also adopted by some Borneo peoples from Indianized South-East Asian sources, but these appear to have been merged with or superimposed on earlier pagan motifs. For example, the ancient Bornean image of serpent or watersnake as a symbol of the Underworld seem to have incorporated the Hindu-Javanese dragon-serpent motif; it is often referred to as naga.

The Hindu-Buddhist influence on people's faith in Kalimantan may have been earlier than the King's assumption, because since approximately $800 \mathrm{AD}$ the western part of the island had become a transit for traders on their way from India to China. It means that the relationship was 500 years earlier than the rise of Hindu Majapahit dynasty in Java (approximately 1300 AD) (See Irwin 1986: 3). Meanwhile, Bellwood (1995) and Collins (1996, 2005c) provided an early age with the discovery of agate beads from India with a bronze drum from the Dongson, Southeast Asia, dated around the 4th century AD. In fact, Kutai kingdom which was a Hindu kingdom had already been in existence on the island of Borneo since the 4th century AD (Abdul Rahman 1985: 28). Even so, the Hindu-Buddhist influence was not really prominent in the interior of West Kalimantan when compared to the influence of religion on society both 
Malays in Peninsular Malaysia as reported Skeat (1900, 1967), Shaw (1975) and Winstedt (1985).

Culture always changes so its nature is usually called dynamics. Cultural changes occur continuously. Tradition as a part of culture also changes from time to time; or at least culturally adaptable. Such changes may originate from within the tradition practitioners or result from the outside influence. Usually, the changes within the tradition holders take place rather slowly when compared with influence from the outside. ${ }^{10}$

In Malay society, such changed can be seen in the cosmology of some people who previously believed in the myth and then replaced it with a new cosmology of tradition which is more empirical in nature. However, this situation does not always apply to the entire Malay community. The beliefs and practices contained in the Ilmu of the Embau society reflect a form of long tradition that goes side by side with new elements which suggest a change in addition to the continuity of tradition. It even applies to the individual i.e. the connection of both of these elements, i.e. the old and the new, are continuous and not dichotomous. ${ }^{11}$

The presence of Islam has brought many changes to the people who then chose Islam as their religion, including in terms of culture. Before Islam came, Embau people had already been familiar with the tradition of bbamai which is similar to chanting mantras used for ceremony of bedewa-besirang. With the changing times, especially with the improvements in education and strength of Islam, this tradition is gone. However ilmu which contains the old belief is still in existence. In other words, most of the old traditions are still existent without significant changes (Hermansyah, 2010: 47).

A number of ilmu texts suggest the Embau people's relationship with Islam in the early stage. They may even have absorbed Islamic elements before they accepted Islam as their religion. Some examples can be presented as evidence to support this assumption. In the text of ilmu na belawan, the practitioner mentions 'astarpirli' [forgive my sins] ${ }^{12}$ followed by tagapirli, whose origin of the word and its meaning is unknown. It suggests a word derived from Arabic as if for the sake of the ' $i$ ' rhyme at the end of the word. ${ }^{13}$ It may also

${ }^{10}$ Changes of tradition are in line with changes in other elements of society. For example, see cultural changes described by Malinowski (1961).

${ }^{11}$ In Embau society, ilmu is not only possessed by ordinary community members, but it is also owned by informal leaders such as village heads, adat leaders or imams.

${ }^{12} \mathrm{Zikr}$ is recited as a statement of confession and asking forgiveness to God [astaghfirli or astaghfirullah].

${ }^{13}$ Haron (2001: 24) who conducted a study on the Malay mantra using the Malay literary approach concluded that one of the characteristics of the Malay mantra is in the form of a recital text built from words or verses in a poem or rhymed prose. 
be the recipient of this ilmu could not capture the original Arabic letter. This condition may be compared to the word neraman in the text of ilmu asar which is practiced by Tunjung and Benuaq Dayak who are Christian as follows:

bismillah neraman arahim sang putih raja manak asal orang putih tak belawan

(Hopes 1997: 112) in the name of Allah, The Merciful and

Compassionate

White Lord, King [of] Children

because of a man's white origin, he shall not resist

Of course, as Hopes responded that the first three words in the text are derived from the verse 'Bismillahirrahmanirrahim' meaning 'in the name of Allah Most Gracious, Most Merciful', but according to Hopes' informants the three words, i.e. bismillah, neraman, arahim are the names of three prophets.

As an open community --the indigenous people of West Kalimantan in the early stages had a contact with the outside culture-it was easy for them to accept foreign culture without considering the religion of the foreigners. For example, a Christian Taman Dayak in West Kalimantan refers to the name of their god as 'Alatala"14, accept the role of Muslim shamans and practice the ilmu taught by these shamans. ${ }^{15}$ One can imagine this condition during Embau people's first encounter with Islamic proselytizers over 150 years ago. Therefore, it is not surprising that the deeds and beliefs contained in Ilmu show a link between Islamic culture and previous culture, including the Hindu-Buddhist.

\section{Another example of a blend of Islamic faith with tradition appears on the} alignment of count of four in ilmu sahabat empat ${ }^{16}$. Four sides seem to have a special value in the minds of the Malay. This belief illustrates the concept of space of the Malay who assume that the nature consists of four sides (Endicott 1991:122). ${ }^{17}$ Perhaps it is the concept of space that the Embau people make

${ }^{14}$ The name of God 'Alatala' in the Taman community which Y.C. Thambun (1998: 77) considered the real name of the God of the Taman people is definitely a loan word of the name 'Allah ta'ala', God of Muslims. The lending process and transition is from 'Allah ta'ala' to ' $[\mathrm{H}]$ alatala' --see Gonda (1973: 218). The Ngaju Dayak people call the name of their god Mahatala, Hatala or Lahatala. In this regard Wilkens (Scharer 1963: 14) wrote," The first of the Arabic expression is Allah ta'ala. A corruption of this name is Hatalla, Lahatalla." Mahatala is a similar corruption.

${ }^{15}$ See (Bernstein 1997).

${ }^{16}$ namely the four companions present at birth, the four companions of the Prophet (Abu Bakr, Umar, Uthman and Ali and four angels (Gabriel, Michael, Israfil, and Azrael) in Islamic tradition.

${ }^{17}$ According to Endicott, the Peninsular Malay believe that all four sides of the world 
mpalang bonih ${ }^{18}$ - That rice is grown with four sides of boundary guarded by Umar, Abu Bakr, Uthman and Ali. This concept should also be compared with Sufi belief about wali quthb zaman that became the axis of the universe. In addition both names of the guardian above, the name of Ahli Kutub Zaman is also mentioned in ilmu i.e. ilmu zikir wali (Hermansyah, 2010: 129). According to Schimmel (1976: 200) in the belief of the Sufis and followers of the tariqa, Qutb is a guardian who becomes the axis of the universe. This guardian at God's blessings is supreme among the other guardians. ${ }^{19}$ Likewise, the space of protection for humans recorded in the ilmu sahabat empat (four companions) above --Israfil on the left, Azrael on the right, Michael at the back, and Gabriel in front, while Muhammad as an umbrella (Hermansyah 2010: 129).

Muhammad's position is not above or below but as a protector, as if as an axis. In a ritual of planting paddy seeds, it is explained that when sowing the four sides with mpalang bonih, the names Abu Bakr, Umar, Uthman and Ali are mentioned. When sowing hole in the middle, the name Muhammad is mentioned. This concept may also be seen in the alignment of 'four' --uri' (lawi '), temuni', tutup and tuban (ntuban) parallel to Umar, Abu Bakr, Uthman and Ali and parallel also to Israfil, Azrael, Michael and Gabriel in ilmu sahabat empat (four companions). In fact, a theme or an emblem of four images or metaphors arise repeatedly in the data corpus of the Embau people's ilmu (Hermansyah, 2010: 129).

Another example, though Islam teaches that man was originally created from soil and the first man was Adam ${ }^{20}$, as recorded in ilmu pakai bepantap and ilmu asal badan manusia, according to a folklore, the Embau ancestors were Ini'

are guarded by four sheikhs in a circular wall of white iron. This concept, according to Endicott, replaces the belief before Islam of the gods, i.e. the god Shiva's children who reside in the same position. According to Skeat (1967: 100) the names of the sheikh who keep the world's four sides are Abdul Kadir, Abdul Muri, the third child's name is not mentioned, and the fourth is Abdul Ali.

${ }^{18}$ Miniature of huma is made of wood that serves as a starting place for planting rice.

${ }^{19}$ The concept is based on Tirmizi's thought (died 932 AD), author of the book Khatamul Anbiya' [The Seal of Saints], who said that qutb or ghauts is an unseen supreme authority. He was surrounded by three nuqaba' guardians, four autad guardians, seven abrar guardians, forty abdal guardians, three hundred akhyar and four thousand hidden guardians (al-Hujwiri 1980, see also Schimmel 1976: 200). Although Tirmizi's thought did not describe the four sides, yet it gave an impression that the world is guarded from many sides. In Shia, Qutb is associated with the highest spiritual leader that is a hidden Imam and some call him Imam Mahdi (Schimmel 1976: 200).

${ }^{20}$ Adam's creation story in the Qur'an among others is contained in Surah al-Hijr verses 28 and 29 . 
Demang Nutup. ${ }^{21}$ Ini' Demang Nutup was where the tribes descended from ${ }^{22}$ and was also a supernatural being that guards the nature ${ }^{23}$ (Hermansyah, 2010: 130).

As already indicated, some old traditions and beliefs still exist without any influence of the teachings of Islam. There is also a tradition that blends with Islamic elements. There is also ilmu that only contains Islamic elements. In practice, even though there is a living system, gradually Islamic elements show 'victory' over tradition. For example in the case of human origins, a lot of ilmu texts have already demonstrated that the theory of creation is heavily influenced by the teachings of Islam. However, at the same time, there is also a story of human origin that comes from the tradition i.e. Ini' Demang Nutup. However, the origin of the story is more directed to the origin of the name of a place, not the origin of man. Another example, belief in ghosts also 'competes' with belief in the devil, demons and jinn. The encounter between traditional belief and Islam is the secret of success of Islamic propagation in Embau or even in the Indonesian archipelago (see Lapidus 1991: 468, Bellah 2000).

The existence of the elements of Sufism in Ilmu is not so strange because certain Sufis do practice specific mantra that can be associated with magic. For example, some followers of the Sadziliah Tariqa in Egypt believe that certain $z i k r$ has magic power, such as hizb al-bahr which is used as a protection spell

${ }^{21}$ Ini'demang nutup's wife was Sunta Bonang. Ini'demang nutup comes from Kayangan in heaven. They both fell to the earth through the Ampan Hill located on Beluan Hill -the two hills were previously one. At that time, the top of the hill was just a few inches from the sky. To get down to the top of Ampan Hill, they use bruru roots (a kind of forest root that creeps on the tree). At one time, the roots were cut by Ini'demang nutup because Siang Burung ghost also used the roots to descend to earth to kill humans. Similarly Ampan Hill, which was previously located on the summit of Beluan Hill in the south of Landau Kumpang village (see Map 1) is now located on the west of Nanga Pedian village (see Map 1). Ampan Hill is in its current position because it was kicked by Ini'demang nutup' was angry because his child ate fish obtained from the pond on the hill.

${ }^{22}$ The ethnic groups mentioned by the narrator are only the Malay, Chinese, Bugis, Taman and Tebidah. Perhaps, the names of these ethnic groups are so well known by the narrator. All of the ethnic groups mentioned are native to the interior of West Kalimantan, except Chinese who were immigrants having already in settled in Jongkong since approximately 100 years ago in quite a large a number. Some of them are married to local people (see Hermansyah 2002).

${ }^{23}$ According to (Leha KP 08/15/2004) Inidemang nutup' had 20 twenty children, some became humans, and some became puaka guarding specific areas in Kapuas Hulu. Ini'demang nutup and Sunta Bonang's children who became humans were the ancestors of various ethnic groups: Malays, Chinese, Bugis, Taman and Tebidah. According to the informant namely Uju (KP 25/06/2004), Ini'demang nutup's children did not all became humans but some became puaka -that is, spirits that resemble certain animals that guard the river. The children who became puaka namely: Ripung, guard of Tawang River in Nanga Suhaid; Kiyai Sendi Arak Belingang, guard of the river in Selimbau; and Patah Golik Pribang Tamang in the Embau River, Jongkong. 
when taking a trip (Schimmel 1976: 178). Likewise, the propagator of Islam in Indonesia, especially Sufis, who are also believed to have the ability to heal by supernatural means that attracted the attention of local people who then became sympathetic to embrace Islam. To them, the Sufis can answer their pragmatic interests. Thus, in the early days of Islamic conversion, the Embau community and like many other Muslims in the archipelago, still lived with a mentality inherited by the local culture and gave birth to Islam with syncretic character. ${ }^{24}$ (see Lapidus 1991: 469, 488). ${ }^{25}$ In this respect, Lapidus (1991: 487 488) stated:

While many Muslims adhered to the high tradition defined by ulama and Sufi teachings, many, if not most lived in a mental world defined by the heritage of local cultures. For most Southeast Asian villagers, Islam was an element of a more complex social and religious identity and not the exclusive symbol of personal and collective life.

This condition is not the same as pictured by Winstedt (1982: 71-73) that the influence of Islam was very limited and mixed with Hindu-Buddhist beliefs. In the next stages, Islam greatly influenced the lifestyle of the Malay in the Indonesian Archipelago. In fact, as stated by Al-Attas (1969: 4-7) that the shift of the Indonesian Malay from the system of Hindu-Buddhist tradition equals to the shift of the Western World's view that was previously influenced by Greek mythology to the world of logic and enlightenment.

\section{CONCLUDING REMARKS}

Belief and practice as part of an existing culture in the Embau community now is not something that grows and develops in an empty room. All of these manifestations serve as a continuity of the treasures of humanity. Derivation and transfer of a culture toward forming a new more complex culture is natural and inevitable. There is no culture and civilization in the world built without relationship and interchange with other cultures and civilizations.

${ }^{24}$ In this paper the term refers to the process of syncretic Islamization not yet perfect, where the encounter between the teachings of Islam and local culture occurs. The term is commonly used by researchers of Islam in the Archipelago such as Geertz (1961), (Lapidus (1991) and Abdul Munir (2000).

${ }^{25}$ Similarly, the role of Islamic religious leaders 'kiyai' in Java with regard to things that are superstitious such as the determination of the day of marriage (Vredenbregt 1990: 62); as well as groups of students who use the verses of the Qur'an for the purpose of healing as reported by Geertz (1989: 118-119). 
This continuity shows that local communities have a vibrant culture passed down from one generation to the next. The existence of tradition heritage in inland Islamic societies of West Kalimantan shows their peaceful process of accepting Islam because Islam accommodates local culture. Such process of Islamization enabled the religion to be accepted in a spectacular manner in the Enbau area, a region located 700 kilometers from the coastal area.

\section{REFERENCES}

Abdul Munir Mulkhan. 2000. Neo-Sufisme dan pudarnya fundamentalisme di pedesaan. Yogyakarta : UII Press.

Abdul Rahman Haji Abdullah. 1985. Asia Tenggara tradisional. Kuala Lumpur: Teks Publishing.

Attas, Syed M. Naquib al-. 1969. Preliminary statement on general theory of Islamization of Malay-Indonesia Archipelago. Kuala Lumpur: Dewan Bahasa dan Pustaka.

Bellah, Robert N. 2000. Beyond belief: menemukan kembali agama, esei-esei tentang agama di dunia modern. Terj. Rudy Harisyah Alam. Jakarta: Paramadina.

Bernstein, Jay, H. 1997. Spirit captured in stone: shamanism and traditional medicine among the Taman of Borneo. Colorado: Lynne Rienner Publisher.

BPS Kalbar. 2005. Kalimantan Barat. http://www.kalbar.bps.go.id/.15 Januari. BPS Kapuas Hulu. 2004. Kapuas Hulu dalam angka 2003. Putussibau:BPS

Cribb, Robert. 2000. Historical Atlas of Indonesia. Honolulu : University of Hawai

Ellen, Roy. 1993. Anger, anxiety, and sorcery: An analysis of some Nuaulu case material from Seram, Eastern Indonesia. Dlm C.W. Watson \& Roy Ellen (pnyt.). Understanding witchcraft and sorcery in Southeast Asia, hlm. 81-97. Honolulu: University of Hawaii Press.

Endicott, K.M.1991. An analysis of Malay magic. Singapore: Oxford University Press.

Enthoven, J.J.K. 1903. Bijdragen tot de geographie van Borneo's Wester-Afdeeling. Jilid 2. Leiden: E.J. Brill.

Geertz, C. 1961. The Javanese family: A study of kinship and socialization. New York: Free Press of Glencoe.

Geertz, C. 1989. Abangan, santri, priyai dalam masyarakat Jawa. Jakarta: Pustaka Jaya.

Gimlette, J.D. 1971a. Malay poisons and charm cures. Kuala Lumpur: Oxford 
University Press.

Gonda, J. 1973. Sanskrit in Indonesia. New Delhi: International Academy of Indian Culuture.

Hamilton, A.W. 1926. Malay love charms. Dlm. Journal of the Malayan Branch of the Royal Asiatic Society. 4 (1): 136-138.

Haron Daud. 2001. Mantera Melayu: Analisis pemikiran. Pulau Pinang: Penerbit Universiti Sains Malaysia.

Hermansyah. 2002. Magi Ulu Kapuas: Kajian atas Ilmu masyarakat Melayu Embau. Tesis MA Program Pascasarjana IAIN Walisongo Semarang.

Hermansyah. 2005. Magic pengasihan Melayu pedalamanan Kalimantan Barat. Dlm James T. Collins \& Hermansyah (pnyt.). Prosiding persidangan antarabangsa The languages and literatures of western Borneo: 144 years research, hlm. 147-158. Bangi: Institut Alam dan Tamadun Melayu, Universiti Kebangsaan Malaysia.

Hermansyah. 2010. Ilmu Gaib di Kalimantan Barat. Jakarta: KPG, EFEO, STAIN, KITLV.

Hopes, Michael. 1997. ILMU Magic and divination amongst the Benuaq and Tunjung Dayak. Jakarta: Puspa SWARA.

Hujwiri, Ali Ibn Usman al-. 1980. The Kashf al-mahjub: The oldest Persian treatise on sufism. Terj. Reynold A. Nicholson. Lahore: Islamic Book Foundation.

J. Hasse, 2011. Dinamika Relasi Islam dan Adat: Pengalaman Towani Tolotang di Sulawesi Selatan. Unpublished Disertation at CRCS-UGM.

Laderman, Carol. 1991. Taming the wind of desire: Psychology, medicine, and aesthetics in Malay shamanistic performance. Berkeley: University of California Press.

Lapidus, Ira M. 1991. A history of Islamic societies. Cambridge: Cambridge University Press.

Malinowski, B. 1961. The dynamics of culture change. New York: Yale University Press.

Maxwell, W.E. 1883. Shamanism in Perak. Journal of the Straits Branch of the Royal Asiatic Society. 12: 222-232.

Moh. Haitami, Hermansyah \& Yusriadi. 2000. Islam di Pedalaman Kalimantan Barat: Studi kasus atas keberagamaan masyarakat Embau. Laporan pengkajian pada Sekolah Tinggi Agama Islam Negeri (STAIN) Pontianak.

Pals, Daniel L. 1996. Seven theories of religion. New York: Oxford University Press.

Schimmel, Annemarie. 1976. Mystical dimension of Islam. Chapel Hill: The University of North Carolina Press. 
Shaw, William. 1972. Black magic. Federation Museums Journal. XVII: 33-59. Shaw, William. 1975. Aspects of Malaysian magic. Kuala Lumpur: Muzium Negara Malaysia.

Skeat, W.W. 1967. Malay magic: being an introduction to the folklore and popular religion of the Malay Peninsula. New York: Dover Publication. [First published 1900]

Sutini Ibrahim. 1996. Senganan. Makalah seminar sehari dalam rangka Festifal Istiqlal II-1995 Daerah Kalimantan Barat. 29 Agustus.

Tylor, E.B. 1974. Primitive culture: research into the development of mythology, philosophy, religion, art and custom. Jilid I. New York: Gordon Press.

Veth, P.J. 1854. Borneo's Wester Afdeeling. Geografisch, statistisch, historisch. Zaltbommel: Joh. Noman en Zoon.

Vredenbregt, Jacob. 1990. Bawean dan Islam. Jakarta: INIS.

Werner, Roland. 1986. Bomoh poyang: The traditional medicine and communal art of the aborigines of Malaysia. Kuala Lumpur: Penerbit Universiti Malaya.

Winstedt, R.O 1985. The Malay magician being shaman, saiva and sufi. Kuala Lumpur: Oxford University Press.

Winstedt, R.O, 1920. Malay charms. Dlm. Journal of the Federation of Malay States Museum. 9: 129-159. 